\section{PAAR SÕNA EMPAATIAST}

Keele ja Kirjanduse eelmises numbris võis lugeda Liina Lukase ülevaadet Balti kirjakultuuri sümpoosionist, mis kandis pealkirja „Kontinent Herder: empaatia, sümpaatia ja antipaatia poeetikas ja poliitikas". Rõõm on näha, et vastukaaluks üldisele suundumusele vähendada vanade keelte osakaalu aineprogrammides ${ }^{1}$ leidub ürituse pealkirjas ainult kolm sõna, mis ei pärine vanakreeka keelest. Nendeks sõnadeks on Herderi nimi, sidesõna ja ladina keelest tulnud "kontinent". ${ }^{2}$

Selleks, kuidas vanakreeka sõnad jõuavad tänapäeva keeltesse, on kaks levinumat rada. Üks neist on järjepidev traditsioon, kus sõna on liikunud kreeka keelest ladina keelde ning ladina keelest ülejäänuisse. Teise võimalusena pöördutakse uut vajalikku terminit otsides otse vanakreeka keele poole ning leitakse sealt (või tuletatakse vanakreeka osistest) meelepärane sõna. Viimane teguviis on laialt levinud meditsiinis ja loodusteadustes. Ülaltoodud ürituse nimes kuuluvad sümpaatia, antipaatia, poeetika ja poliitika esimesse, empaatia aga teise rühma. Sõna $\varepsilon \mu \pi \alpha \dot{\alpha} \theta \varepsilon \alpha^{3}$ eksisteeris küll juba antiikajal, kuid tähistas igasugust tugevat tunnet, kirge, tungi (eesliide $\dot{\varepsilon} v-/ \dot{\varepsilon} \mu-$ näitab seesolemist, $\tau \dot{\alpha} \theta o \varsigma$

${ }^{1} \mathrm{Nt}$ viimase kärpena õpivad alates 2015 . aasta sügisest Tartu Ülikoolis soome-ugri filoloogid kohustuslikult ladina keelt kahe semestri asemel ainult ühe. Sellised arengud mõjutavad otseselt pealekasvavate põlvede oskusi korrektselt kasutada ja translitereerida kreeka ja ladina keelest tulnud sõnu.

${ }^{2}$ Continēns 'katkematu, jätkuv, pidev'.

3 Samuti sellega seotud omadussõna $\varepsilon \dot{\varepsilon} \mu \alpha \theta \dot{\eta} \varsigma$ ja määrsõna $\dot{\varepsilon} \mu \pi \alpha \theta \tilde{\omega} \varsigma$. on aga tundmus, kogemus, kannatus). ${ }^{4}$ Oma tänase tähenduse omandas empaatia XIX-XX sajandil, kui läks vaja rahvusvahelist terminit, et tähistada saksa Einfühlung'it, mis oli kontseptuaalselt tähtis juba Herderil ning Novalisel, kuid omandas termini staatuse Robert Vischeri (1847-1933) esteetikateoorias: nn Einfühlungstheorie, mis seostab vaatleja tunnete kaudu vaadeldava objektiga. ${ }^{5}$ Järgnevalt arendas oma Einfühlungstheorie'd Theodor Lipps (1851-1914). Empaatia Einfühlung'i vastena võttis ilmselt esmakordselt 1909. aastal kasutusele Edward Bradford Titchener, tõlkides Lippsi mõistet, mille jaoks puudus inglise keeles sobilik sõna. ${ }^{6}$ Tähenduselt on Einfühlung'ile vanakreeka keeles lä-

${ }^{4}$ A Greek-English Lexicon: With a Revised Supplement. Koost H. G. Liddell, R. Scott, sir H. S. Jones. Oxford: Clarendon Press, 1996, lk 542 .

${ }^{5}$ Friedrich Maureri ja Heinz Ruppi „Deutsche Wortgeschichte" andmeil substantiivi Einfühlung siiski Herderil ja Novalisel ei lei$\mathrm{du}$, küll aga verb sich hineinfühlen. Substantiiv näibki tekkivat koos esteetilis-psühholoogiliste teooriatega, varaseim tuvastatud kasutus Robert Vischeri dissertatsioonis „Das optische Formgefühl" (1872). Terminit asus kasutama ka tema isa Friedrich Theodor Vischer. Vt F. M a u r e r, H. R u p p, Deutsche Wortgeschichte, Bd. II. Berlin-New York: Walter de Gruyter, 1974, lk 106-107.

${ }^{6}$ E. B. Titch en er, Lectures on the Experimental Psychology of the Thought-Processes. New York: The Macmillan Company, 1909, lk 21: „This is, I suppose, a simple case of empathy, if we may coin that term as a rendering of Einfühlung...." Vt ka: S. Li e k a m, Empathie als Fundament pädagogischer Professionalität: Analysen zu einer vergessenen Schlüsselvariable der Pädagogik. Dissertatsioon. München, 2004, lk 27. 
hedasem hoopis $\sigma v \mu \pi \alpha \dot{\theta} \theta \varepsilon \dot{ } \alpha$ (kaastunne, osavõtlikkus; eesliide $\sigma v v-/ \sigma v \mu$ - kannab tähendust 'koos-, kaas-'), kuid selle vasteks oli saanud eeskätt saksa Mitgefühl. Nagu eelnevast nähtub, on Herderi puhul otse kreeka sõnale $\dot{\varepsilon} \mu \pi \dot{\alpha} \theta \varepsilon \iota \alpha$ viidata siiski kergelt ekslik.

Tuleb veel märkida, et tänapäeva kreeka keelde on $\varepsilon \mu \pi \dot{\alpha} \theta \varepsilon \alpha^{7}$ jõudnud ka järjepideva traditsiooni tulemusel. Nii on ta seal säilitanud oma kunagise kire tähenduse, kuid lisandunud on irooniliselt hoopis negatiivne värving: $\varepsilon \mu \pi \alpha \dot{\alpha} \theta \varepsilon \iota \alpha$ tähistab ka vaenulikkust, pahatahtlikkust, õelust. ${ }^{8}$ Näiteks ilmus 23. augustil

\footnotetext{
${ }^{7}$ Sic! Praeguses kreeka keeles ei kasutata enam hõngusmärke.

${ }^{8}$ D. N. Stavropoulose kreeka-inglise sõnastik annab nimisõna $\varepsilon \mu \pi \alpha \dot{\theta} \theta \varepsilon \iota \alpha$ vasteteks 'passion, hatred, bitterness', omadussõna $\varepsilon \mu \pi \alpha \theta \eta \dot{\zeta}$ on aga tähendustega 'malicious, spiteful, malevolent'. Vt Oxford Greek-English Learner's Dictionary. Koost D. N. Stavropoulos. Oxford: Oxford University Press, 1988, lk 283.
}

2015 ajalehes To $\beta \eta \mu \alpha$ artikkel pealkir-

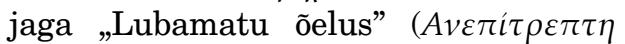

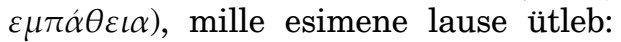
„Paistab, et inimloomus on selline, et ei suuda vältida väiklust ja õelust"

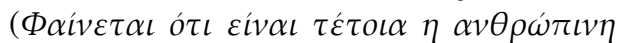

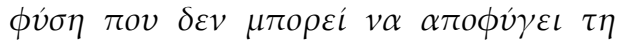
$\mu \iota \kappa \rho о \psi v \chi i \alpha \kappa \alpha \iota \tau \eta v \varepsilon \mu \pi \alpha \dot{\theta} \theta \varepsilon \iota \alpha){ }^{9}$

NEEME NÄRIPÄ

${ }^{9}$ Näite ja selle tõlkimise eest on repliigi autor tänulik Kaarina Reinule. Artiklit saab originaalis lugeda siin: http://www.tovima.gr/ opinions/article/?aid=731129. 